\title{
PENINGKATAN KEWASPADAAN BENCANA ASAP DI KECAMATAN DAYUN KABUPATEN SIAK
}

\author{
Amir Syamsuadi ${ }^{1}$, Diki Arisandi ${ }^{2}$, Tengku Fahrul Gafar ${ }^{3}$, Liza Trisnawati $^{4}$ \\ Seri Hartati $^{5}$, M. Fajar Anugerah ${ }^{6}$ \\ 1,3,5,6) Program Studi Ilmu Pemerintahan, Fakultas Ilmu Sosial dan Ilmu Politik, Universitas Abdurrab \\ ${ }^{2,4,)}$ Program Studi Teknik Informatika, Fakultas Teknik, Universitas Abdurrab \\ e-mail : amir.syamsuadi@univrab.ac.id
}

\begin{abstract}
Abstrak
Pengabdian kepada masyarakat ini dilaksanakan di Kecamatan Dayun Kabupaten Siak. Adapun materi yang disampaikan adalah model pencegahan kabut asap akibat kebakaran hutan dan lahan (karhutla) berbasis sistem informasi dan penguatan kebijakan mengenai kebencanaan. Kegiatan ini berguna bagi masyarakat dan stakeholder terkait mengenai pentingnya meminimalisir bencana asap dan Potensi kebakaran hutan dan lahan. Aspek sistem Informasi yang disampaikan yakni melakukan deteksi asap dengan menggunakan alat pendeteksi asap dan aspek kebijakan yakni mengarahkan kembali masyarakat untuk mematuhi aturan terkait seperti peraturan desa, peraturan daerah dan undang-undang mengenai kebencanaan. Adapun dampak yang diperoleh dari kegiatan ini adalah meningkatnya kesadaran dan kewaspadaan masyarakat terhadap bencana asap di Kecamatan Dayun Kabupaten Siak.
\end{abstract}

Kata kunci: Peningkatan, Kewaspadaan, Bencana, Asap

\section{Abstract}

Community service is carried out in Dayun District, Siak Regency. The material presented was a master plan to prevent smoke haze due to forest and land fires (forest and land) based on information systems and strengthening policies on disaster. This activity is useful for the community and stakeholders related regarding the importance of minimizing smoke disasters and the potential for forest and land fires. Information system aspects that are delivered namely smoke detection using smoke detection devices and policy aspects namely redirecting the community to comply with relevant rules such as village regulations, local regulations and laws on disaster. The impact of this activity is the increased awareness and awareness of the community towards the smoke disaster in Dayun District, Siak Regency.

Keywords: Increase, Alert, Disaster, Smoke

\section{PENDAHULUAN}

Bencana Kebakaran hutan dan lahan (Karhutla) menjadi hal yang sangat mengkhawatirkan bagi kehidupan manusia. Tingkat volume pencemaran udara akibat Karhutla sangat mengganggu siklus kehidupan manusia yang hakikatnya sangat membutuhkan hak hidup dan mendapatkan kesehatan. Pemerintah merupakan bagian penting dalam hal pemberian layanan publik dan tata kelola pemerintah. Tata pemerintahan adalah penggunaan wewenang ekonomi, politik dan administrasi guna mengelola urusan urusan negara pada semua tingkat (Syamsuadi, 2018). Tata kelola pemerintahan yang baik dalam segala aspek termasuk kesiagaan bencana sangat diperlukan, sehingga masyarakat mendapatkan rasa keamanan dan kenyamanan dalam menjalani tatanan kehidupannya.

Bencana asap yang diakibatkan kawasan hutan dan lahan Kecamatan Dayun Kabupaten Siak terbakar secara luas setiap tahunnya diindikasikan dengan banyaknya titik panas (hotspot). Kecamatan Dayun dekat dengan wilayah operasional perusahaan, dimana instansi pemerintah dan 
masyarakat, termasuk petani, perusahaan-perusahaan perkebunan dan HTI, merupakan siklus kebakaran hutan dan lahan. Sebagian besar mata pencaharian masyarakat Kecamatan Dayun yaitu sebagai petani di perkebunan sawit.

Melihat tingginya titik api hingga bulan agustus 2019 di Riau mencapai 116 titik, dan penyumbang titik api terbesar didaerah Kabupaten Siak Kecamatan Dayun. berasal dari lahan gambut dan lahan sawit. Akibatnya, jumlah penderita ISPA di daerah Riau meningkat menjadi 3878 jiwa (Kompas.com, 2020). Ada beberapa hal yang mendasari mengapa kerap terjadi kebakaran hutan dan mengapa Siak khususnya Kecamatan Dayun menjadi tempat penyumbang asap dan penderita ISPA. Berdasarkan data yang didapat dari pemerintah Kabupaten Siak, Kecamatan Dayun merupakan daerah dengan $70 \%$ lebih lahan gambut serta memiliki kandungan minyak bumi (Prayitno, Prisha, \& Herlina, 2011).

Menurut informasi yang didapat dari wawancara dilapangan bahwa pemicu Karhutla yang yang memicu bencana asap pada saat musim kemarau di Kecamatan Dayun diantaranya adalah karena faktor manusia, misalnya seperti membakar hutan dan lahan yang dilakukan oleh oknum-oknum masyarakat yang tidak bertanggung jawab untuk membuka lahan perkebunan. Adapun faktor alam sangatlah kecil kemungkinan terjadi.

Banyaknya aktivitas manusia dalam pembukaan lahan untuk dijadikan sebagai lahan pertanian dan perkebunan yang memicu terjadinya kebakaran hutan dan lahan. Penyiapan lahan dengan cara pembakaran dianggap sebagai metode yang lebih murah, mudah dan cepat, masyarakat berpikir bahwa dengan cara membakar hutan maka kegiatan perkebunan jadi lebih mudah padahal hal itu tentu sangat merusak dari segi ekosistem pencegahan (Harahap, D.K., Yoza, D., Oktorini, 2017). Perusakan hutan telah berkembang menjadi suatu tindak pidana kejahatan yang berdampak luar biasa dan terorganisasi serta melibatkan banyak pihak, baik nasional maupun internasional (Daoudi, 2000).

Teknologi memegang peranan penting yang dapat meningkatkan fungsi informasi pada enterprise, sosial, publik dan lingkungan bisnis (Hartati, Syamsuadi, \& Elvitaria, 2020). Berangkat dari hal tersebut maka perlu adanya alat atau aplikasi yang memudahkan dalam pencegahan bencana asap akibat kebakaran hutan dan lahan dan memandang perlunya secara masif penginternalisasian aturan-aturan yang berhubungan dengan aspek kebencanaan yang disebabkan oleh kebakaran hutan dan lahan yang terjadi kawasan Kecamatan Dayun Kabupaten Siak. Sehingga kedepannya bencana asap dapat diminimalisir dengan sebaik-baiknya dan masayarakat semakin sadar akan pentingnya menjaga alam dan lingkungannya.

\section{METODE}

Penyelesaian permasalahan dari pengabdian ini yang pertama dilakukan adalah pembuatan aplikasi pendeteksi asap yang dilakukan oleh pengabdi masyarakat yang berlatarbelakang teknik informatika yakni dengan cara merancang pembuatan alat pendeteksi asap yang kemudian dipasang pada kawasan lahan dan hutan yang potensial terjadinya bencana kebakaran. Kemudian langkah kedua adalah upaya penguatan dan edukasi pemahaman kepada masyarakat setempat mengenai pentingnya pencegahan kebakaran hutan dan lahan dalam perspektif regulasi dan kebijakan yang dalam hal ini dilakukan oleh tim pengabdi masyarakat dengan latarbelakang ilmu sosial. Pengabdian dimulai dari bulan Desember 2019 hingga Februari 2020.

\section{HASIL DAN PEMBAHASAN}

Pengabdi membuat inisiasi Kampung Siaga Api yang ditujukan kepada warga dengan membentuk satuan Badan Relawan Kebakaran (BALAKAR), tim pengabdi juga memberikan usulan kebijakan tata kelola penanganan bencana kebakaran bagi pemerintah setempat dengan membuat rancangan paket kebijakan Desa Tangguh Bencana (DESTANA) program yang mendukung peraturan kebencanaan dan meningkatkan keterampilan masyarakat dalam pencegahan kebakaran hutan dan lahan melalui Masyarakat Peduli Api (MPA). 


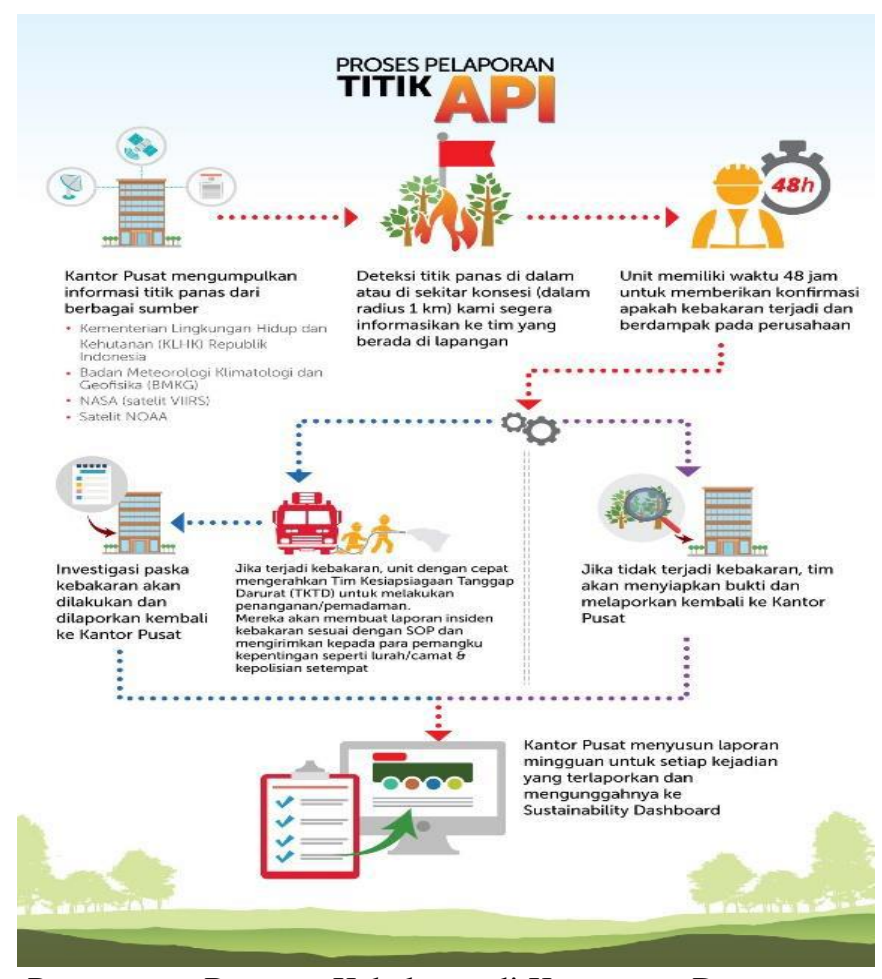

Gambar 1. Model Alur Penanganan Bencana Kebakaran di Kecamatan Dayun

Selain itu sebagai deteksi dini asap dan kebakaran lahan, tim pengabdi akan mengimplementasikan rancangan prototype sistem pendeteksian kebakaran berbasis sensor yang terhubung dengan perangkat telekomunikasi yang ditempatkan dititik yang rawan sehingga peringatan akan dapat sampai ke pihak terkait seperti dinas kebakaran, kantor Desa, maupun kantor Kecamatan.

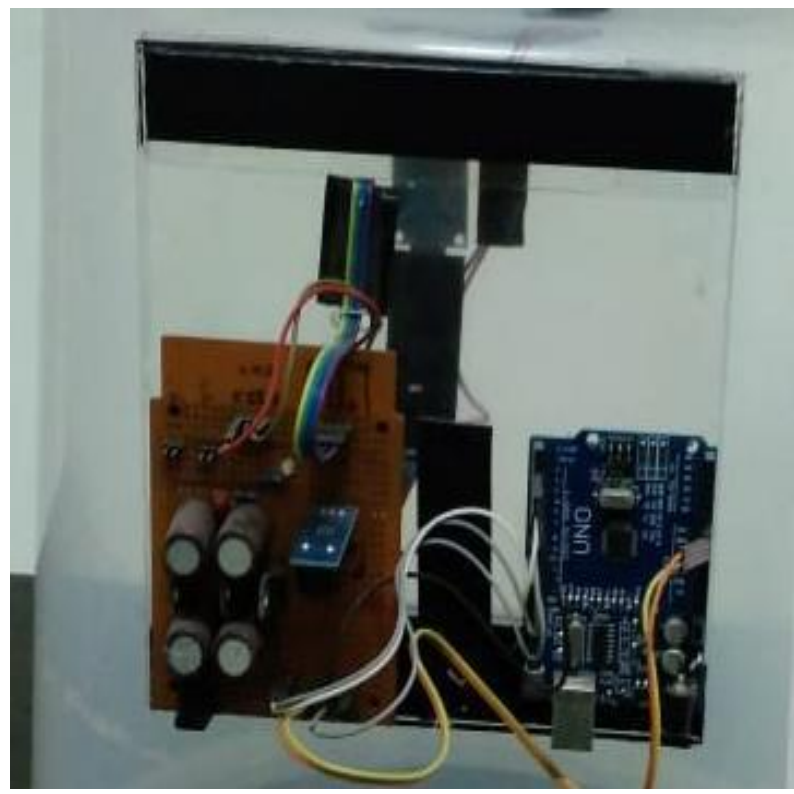

Gambar 2. Rancangan Sensor Pendektesi Asap

Dengan adanya rancangan masterplan kampung siaga api yang dibangun, diharapkan akan ada pengurangan titik api, kasus bencana asap, dan kasus ISPA dikarenakan asap yang timbul di daerah Kecamatan Dayun. 


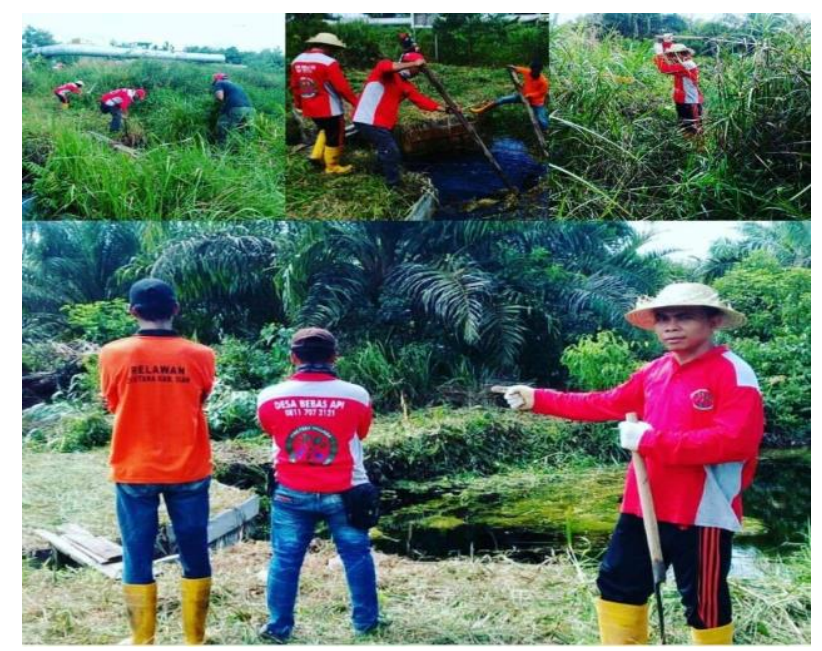

Gambar3. Penghulu Kampung Dayun bersama Tim Pengabdi melakukan survey lokasi pemasangan alat di areal rawan kebakaran di Kecamatan Dayun (Sumber: Observasi Lapangan, 2020)

Kampung Siaga Api ini akan menjadi kampung percontohan pertama yang aware terhadap api. Melalui teknologi pendeteksi kebakaran dini, akan membantu Badan Penanggulangan Bencana Daerah Kabupaten Siak untuk siap siaga dalam menghadapi kebakaran khususnya di Kecamatan Dayun sebagai upaya dalam meningkatkan kinerja program pendataan lahan dan tata guna lahan milik masyarakat serta sebagai upaya membentuk sarana dan prasarana pencegahan kebakaran hutan dan lahan bagi masyarakat dan penegakan hukum yang tegas.

\section{SIMPULAN}

Pengabdian ini merupakan bagian dari sosialisasi pendukung yang juga telah dilakukan oleh pemerintah di Kecamatan Dayun berbasis penerapan sistem aplikasi teknologi informasi. Pengabdian ini juga memberikan edukasi dan peringatan kewaspadaan kepada masyarakat akan bahaya bencana kabut asap terhadap kesehatan manusia dan dampak kelestarian ekosistem hutan akibat kebakaran hutan dan lahan. Pengabdian juga mensosialisasikan aspek yuridis bagi pelaku pembakaran hutan dan lahan.

\section{UCAPAN TERIMA KASIH}

Ucapan terimakasih kami haturkan setinggi-tingginya kepada LPPM Universitas Abdurrab serta Kementerian Riset Teknlogi Pendidikan dan Kebudayaan Republik Indonesia.

\section{DAFTAR PUSTAKA}

Daoudi, M. (2000). Pembinaan Dan Pengendalian Kawasan Hutan Di Provinsi Riau. Journal of Visual Languages \& Computing, 11(3), 287-301.

Harahap, D.K., Yoza, D., Oktorini, Y. (2017). Strategi Pencegahan Kebakaran Hutan Dan Lahan Berdasarkan Persepsi Masyarakat Di Desa Dayun Kabupaten Siak. Jurnal Online Mahasiswa Fakultas Pertanian Universitas Riau (JOM FAPERTA UNRI), 4(1), 1-11.

Hartati, S., Syamsuadi, A., \& Elvitaria, L. (2020). Tranformasi Manajemen Universitas menggunakan Framework Cobit 5 di Era Industri 4.0. Ganaya: Jurnal Ilmu Sosial Dan Humaniora, 3(1), 163-174.

Kompas.com. (2020). https://regional.kompas.com/. Diambil dari https://regional.kompas.com/read/2020/01/02/13151131/awal-2020-karhutla-di-riauhanguskan-1-hektar-lahan-gambut diakses tanggal 15 januari 2020

Prayitno, J., Prisha, R., \& Herlina, S. (2011). Formulasi konsorsium mikroba asal pertambangan minyak Siak Riau yang efektif dalam mendegradasi senyawa hidrokarbon. Jurnal Teknologi Lingkungan, 12(2), 123-130.

Syamsuadi, A. (2018). Membangun Demokrasi Pemerintahan di Riau Dalam Perspektif Budaya Melayu. Jurnal Dinamika Pemerintahan, 1(1), 1-10. 